DOI: 10.35757/RPN.2009.17.06

Piotr Łysakowski

\title{
GLOSA DO LISTU BISKUPÓW POLSKICH DO BISKUPÓW NIEMIECKICH Z 18 LISTOPADA 1965 ROKU W DOKUMENTACH INSTYTUTU PAMIĘCI NARODOWEJ
}

\section{Wprowadzenie}

„[...] Rozpoczęty w dokumentach biskupich dialog w przedmiocie granicy polskiej na Odrze i Nysie nie przyniósł Polsce niczego dobrego. Biskupi niemieccy, ważąc słowa i nie zajmując bezpośrednio stanowiska $\mathrm{w}$ tej sprawie, w sposób pośredni i zdecydowany stanęli na gruncie rewizjonistycznym. Podjęta w piśmie biskupa Choromańskiego nieudolna próba zinterpretowania listu biskupów niemieckich, jako dokumentu »o nastawieniu do naszych Ziem Zachodnich wręcz przeciwnym niż rewizjonistyczne« jest niestety zupełnie bezpodstawna. [...] Dla Niemiec »nieszczęśliwe skutki wojny « wyrażają się przede wszystkim w powrocie Polski na ziemie zachodnie i północne i w przesiedleniu Niemiec z tych terenów. Nutą współczucia dla Niemiec potwierdza to orędzie biskupów polskich w słowach: »...polska granica na Odrze i Nysie, co rozumiemy dobrze, jest dla Niemiec gorzkim owocem ostatniej wojny... wraz z cierpieniem uchodźców i wypędzonych Niemców«. [...] Biskup Choromański użył w swym piśmie zwrotu, że orędzie ${ }^{1}[. .$.$] nacechowa-$

1 Pełna treść listu, nazwanego później „Orędziem” (podpisanego przez Prymasa Stefana Wyszyńskiego dnia 13 listopada 1965 roku i później cały Episkopat Polski) i od- 
ne jest »gotowością przebaczenia«. W rzeczywistości biskupi polscy, nawet bez uprzedniej prośby [...] wybaczyli Niemcom wszystkie zbrodnie, jakich dopuściły się Niemcy [...] wobec Polski i narodu polskiego. Łącznie ze zbrodnią ludobójstwa . Biskupi mówią przecież w swym orędziu do biskupów niemieckich: »... wyciągamy do Was nasze dłonie z ław kończącego się Soboru, udzielamy przebaczenia i prosimy o przeba$\underline{\text { czenie }^{2}}$. [...] Żadne dokumenty biskupie nie mogą wymazać hitlerowskich zbrodni wojennych i zbrodni przeciw ludzkości. Nie zostaną one ani zapomniane ani wybaczone. Nie jest to problem zemsty, czy moralności, lecz sprawiedliwości. Prośba autorów orędzia o udzielenie przez biskupów niemieckich przebaczenia narodowi polskiemu, który nie ma na sumieniu żadnych win, nie dopuścił się żadnych zbrodni wobec Niemców, a tylko stanął $\mathrm{w}$ obronie swej ojczyzny napadniętej przez Niemcy [...] - jest dla narodu polskiego wprost obrażająca i poniżająca jego godność. [...] Od hierarchii kościelnej niczego więcej się nie domagamy, tylko lojalności wobec Polski Ludowej [...] Jednak część episkopatu, na czele z kardynałem Wyszyńskim, pozostała na swoich dawnych, [...] pozycjach walki z socjalizmem, [...] antykomunizmu zaćmił $\mathrm{w}$ ich umysłach poczucie patriotyzmu, zaćmił fakt, że walka z komunizmem uderza rykoszetem w granice Polski na Odrze, Nysie i Bałtyku, godzi faktycznie w niepodległy byt narodu polskiego. Kapitalistyczno-obszarnicza Polska zeszła bezpowrotnie z dziejów historii narodu polskiego. Na mapie Europy państwo polskie może figurować tylko jako państwo socjalistyczne ${ }^{3}$. [...] Rząd PRL, organa władzy państwowej, nie prowadzą ani nie chcą prowadzić walki z kościołem, [...] część hierarchii kościelnej na czele z kardynałem Wyszyńskim wyszła z konstytucyjnych ram [...] podjęła walkę z rządem, z władzami Polski Ludowej, [...] władze państwowe muszą na to reagować, [...] Ta część hierarchii kościelnej, która gwałci ustawę zasadniczą [...] nie może liczyć na tole-

powiedź strony niemieckiej (ta z kolei została wystosowana do strony polskiej 5 grudnia 1965 roku) w: Kościót w Polsce Ludowej: Kościót katolicki a państwo w świetle dokumentów 1945-1980, oprac. P. Raina, t. 2: Lata 1960-74, Poznań, s. 356-364.

2 Podkreślenie w tekście publikowanego dokumentu - P.Ł.

3 Jak dziś widać, zapowiedzi, że terytorialny kształt Polski jest ściśle związany z ustrojem socjalistycznym, i że Polska może trwać w swoim naturalnym, uformowanym po wojnie otoczeniu geopolitycznym, tylko jako państwo socjalistyczne, były prostym urojeniem rządzących. 
rancję ze strony państwa i opinii publicznej. Nie otrzyma też paszportów ${ }^{4}[\ldots]$ dopóki nie zajmie lojalnej postawy wobec państwa, wobec Polski Ludowej. [... $]^{5 \prime \prime}$.

Fragmenty listu byłego premiera PRL Józefa Cyrankiewicza cytowane wyżej, a odnoszące się do „Orędzia Biskupów Polskich do Niemieckich", charakteryzujące doskonale atmosferę, jaka zapanowała w kręgach komunistycznej władzy po inicjatywie Episkopatu Polski z 1965 roku i reakcji Episkopatu Niemiec na tę inicjatywę (5 grudnia 1965 roku), znalazły się w teczkach komunistycznej policji politycznej, które trafiły do Instytutu Pamięci Narodowej.

PRL-owskie służby specjalne (co oczywiste) odnotowywały reakcje na to wystąpienie, jakie pojawiały się poza granicami Polski. W polu obserwacji znalazły się m.in. „Katholische Nachrichten Agentur"6 [dalej KNA - Katolicka Agencja Informacyjna - P.Ł.] i, co ciekawe, polskie wydawnictwa "narodowe” z Francji ${ }^{7}$. Analizowano też wypowiedzi czołowego „Polakożercy” (jak określała go komunistyczna propaganda) Herberta Czaji ${ }^{8}$.

4 Mało kto zwrócił uwagę na to, że w cytowanym wyżej liście Cyrankiewicz mówi wręcz o łamaniu przez władze ustawy zasadniczej PRL, na przestrzeganie której sam się wielokrotnie i górnolotnie powołuje.

5 Dokument list („Do Księży Biskupów Kościoła Rzymsko-Katolickiego na ręce Sekretarza Episkopatu Zygmunta Choromańskiego") Józefa Cyrankiewicza ( ${ }^{*} 1911+1989$, Premiera RP 1947-1952 i PRL 1954-1970) w dokumentach MSW dotyczących kwestii „Orędzia Biskupów” - sygn. IPN BU 1439/64, s. 31, 33, 35, 39, 40,

6 Na stronie $181 \mathrm{w}$ teczce IPN BU 0445/12 t.1/2 znajdują się oceny wystąpienia Józefa Cyrankiewicza przytaczane przez KNA (nr 58 z dnia 9 marca 1966 roku) za „Neues Deutschland", a więc za organem SED, w których podkreśla się, że Polska Ludowa nie będzie tolerowała ze strony Kościoła katolickiego naruszania konstytucji PRL; na podobną tolerancję Kościół nie będzie też mógł liczyć ze strony opinii publicznej.

7 Strona 112 (koperta nr 109) w teczce IPN BU 0445/12 t.1/2 wycinki z gazet w tym z „Narodowca” wydawanego w Lens, gdzie znajduje się artykuł „wydawcy i współzałożyciela tego periodyku Michała Kwiatkowskiego. Pisze on w tekście „Prawdziwe przyczyna ataku Cyrankiewicza na obchód tysiąclecia Chrztu Polski i na Kardynała Wyszyńskiego": „...zawziętość tę [...] można tłumaczyć przede wszystkim obawą że uroczysty obchód [...], wykaże światu, iż religia katolicka [...] jest także dziś naczelnym czynnikiem życia polskiego [...] Komunizm tak zwany polski nie jest [...] tak wrażliwy na interesy narodu polskiego jak biskupi niemieccy na cele niemieckie. Stalin chcąc stworzyć dzisiejszą Polskę rządzoną przez komunistów, musiał powywieszać cały prawie zarząd przedwojennej partii komunistycznej, który żadnej Polski nie chciał [...]".

8 Niemiecki polityk $\left({ }^{*} 1914+1997\right)$ urodzony w Cieszynie, poseł do Bundestagu (CDU), Prezydent i honorowy Prezydent "Związku Wypędzonych". Analizie podda- 
Wśród licznych dokumentów, na jakie natknąłem się w archiwum Instytutu, pewną część stanowią materiały, z którymi badacze problemu nie mieli się jeszcze okazji zapoznać. Mam wrażenie, że nie zmienią one zasadniczo naszej wizji zdarzeń związanych z "problematyką Orędzia” i nie pomogą udzielić precyzyjnej odpowiedzi na nadal nurtujące badaczy liczne pytania z tym związane. Niniejszy materiał nie "przebuduje” generalnie naszej wiedzy o problemie „Orędzia”. Nie zmieni też znacząco opinii na temat jego znaczenia i skutków dla stosunków polsko-niemieckich, może jednak w sposób istotny wzbogacić naszą wiedzę na temat sposobów myślenia władzy w Polsce i roli, jaką w kształtowaniu tego myślenia w odniesieniu do Kościoła katolickiego odgrywała policja polityczna PRL. Nie zmienia to jednak faktu, że dokumenty z archiwów IPN mogą w sposób znaczący uzupełnić naszą wiedzę związaną z tematem i tym samym rozszerzyć wizję zdarzeń z 1965 roku i lat późniejszych.

Warto więc krótko i na potrzeby tych właśnie badaczy ${ }^{9}$, którzy zajmują się problematyką „kościelną”, krótko pokazać zawartość wspomnianych zbiorów. Zawierają one nie tylko dokumenty wytworzone przez polskie "specsłużby", ale także i te, które powstawały w siedzibie STASI w Berlinie ${ }^{10}$. Liczne są relacje z rozmów z niemieckimi „informatorami” polskich służb i „dyplomatów”, wyciągi z niemieckiej prasy (w tym katolickiej), analizy wystąpień polskich biskupów broniących swoich racji wobec wiernych, opinie tajnych źródeł informacji SB odnoszące się do istoty "Orędzia”, odwołanie się do badań socjologicznych

ne było przemówienie Czaji przekazane w sprawozdaniu zatytułowanym „Katolicyzm niemiecki a Europa i sąsiedzi Niemiec"; zawierało ono informacje o przeprowadzonym w Münster (1964) roboczym spotkaniu „Komitetu Centralnego Niemieckich Katolików” i jako dokument przekazany przez źródło „Rogoziński” znajduje się w teczce o sygnaturze IPN BU 02011/15 na stronach 40-34 i nn. [taka numeracja w aktach - PŁ]. Pewnymi aspektami wypowiedzi Czaji zajmiemy się niżej.

9 Oprócz pomnikowej pracy dotyczącej Kościoła katolickiego w Polsce pióra J. Żaryna warto tu przypomnieć m.in. liczne publikacje P. Madajczyka: Przebaczamy i prosimy o... („Więż” 1990, nr 9, s. 112-124, A. Dudka: Komuniści i Kościót w Polsce 1945-1989, Kraków 2003, a także szczegółowe opracowanie J. Swastka dotyczące metropolii wrocławskiej: Rządzący Archidiecezji Wrocławskiej w latach 1945-1995, Wrocław 1998.

${ }_{10}$ Tu przy okazji nasuwa się postulat badawczy o przeprowadzenie badań dotyczących „partnerskiej” współpracy polskiej SB i STASI prowadzący do tego, by nie koncentrować się tylko na polskich nazwiskach znajdujących się archiwach pozostałych po służbach NRD. 
prowadzonych wśród polskiej młodzieży szkolnej, a mających obrazować jej zdecydowanie negatywny stosunek do inicjatywy i postępowania Kościoła ${ }^{11}$.

Jako komentarz do powyższego należy dodać, iż efekty wspomnianych badań, co oczywiste, były oparte na niepełnych i zafałszowanych informacjach przekazywanych ankietowanym przez media i „pedagogów”.

Dla jasności opisu podzielimy, w sposób uproszczony, występujące w aktach dokumenty na grupy dotyczące „spraw niemieckich” i niemieckich reakcji na inicjatywę polskich biskupów. W tej części znajdą się również niemieckie opinie o polskim Kościele, przekazywane i wyrażane $\mathrm{w}$ dokumentach agenturalnych $\mathrm{SB}$. Zapoznamy się też z reakcjami Kościoła na nagonkę inspirowaną ukazaniem się „Orędzia” przez pryzmat tajnych służb Polski Ludowej.

Echa sprawy pojawiały się $\mathrm{w}$ dokumentach, $\mathrm{z}$ którymi się zetknąłem, dość długo - bo nawet do początku lat siedemdziesiątych. $Z$ tego też powodu w artykule znajdą się także opinie jej dotyczące np. z roku 1968. Nie powinno to czytelnika dziwić.

Dodać też należy, że dostępne dokumenty, jeśli chodzi o ich treść, są znacznie "spokojniejsze” od reakcji ówczesnych mediów. Nie oznacza to jednak, by były indyferentne - wręcz przeciwnie.

\section{„Sprawy niemieckie"}

Jest charakterystyczne, że „Orędzie” stało się, czego nikt się nie spodziewał, istotnym elementem gry politycznej odnoszącej się do państwowości NRD ${ }^{12}$. W tej kwestii zwracano uwagę na suwerenność wspom-

${ }^{11}$ Tekst „Na marginesie pewnej ankiety - Młodzież a orędzie (ankieta przeprowadzona w XI klasie którejś ze szkół w woj. Bydgoskim)” znajdujący się w teczce IPN BU 0445/12 t. 1/2. s. 246. Oto fragmenty z podsumowania: „[...] Warto zwrócić uwagę na takie momenty, występujące $\mathrm{w}$ wypowiedziach, jak potępienie nielojalności episkopatu wobec rządu PRL, ujemna ocena prób prowadzenia własnej i ponadpaństwowej polityki, uzewnętrznianie oburzenia na brak godności narodowej autorów »orędzia« [...] Niewątpliwym brakiem wypowiedzi ankietowanych jest całkowite pominięcie NRD i jej roli, choć nie ulega wątpliwości, że nawet tam, gdzie autor pisze »Niemcy « ma na myśli NRF, rząd boński, odwetowców i rewizjonistów [...]".

${ }_{12}$ Notatka/streszczenie dotycząca artykułu z „Volksbote" odnoszącego się do propagandy PAX-u (23 października 1965 pojawiająca się w aktach 27 października 1965 
nianego wyżej państwa i wiążące się z tym uznanie przez nie granicy na Odrze i Nysie. Przeciwstawiano to niepewnemu losowi młodej republiki: „[...] która jako »odwetowa, zaborcza i militarna« jest znieważana [...]"13. Inicjatywa polskich biskupów wywołała też niemałe zamieszanie i zaniepokojenie właśnie wśród „towarzyszy” z NRD, którzy obawiali się pozytywnego podejścia ówczesnego państwa polskiego, czy bardziej czynników partyjnych, do próby stabilizowania stosunków polsko-zachodnioniemieckich ${ }^{14}$, mogących podważać pozycję ich ",socjalistycznej ojczyzny". Podobne reakcje, co urzędnicy MSZ NRD, artykułowali politycy marginalnych, w ustroju komunistycznym, partii, pojawiających się $\mathrm{w}$ chwilach napięcia (by legitymizować reżim Waltera Ulbrichta ${ }^{15}$ ) na scenie politycznej. Ich głosy były także rejestrowane przez SB. Reprezentanci Ost-CDU [Christlisch-Demokratische Union Deutschlands] uznawali zwracanie uwagi na „Orędzie” przez władze polskie, w dłuższej perspektywie, za błąd: „,...] lepiej było listów po prostu nie zauważyć publicznie, a tylko reagować wewnętrznie [...]". Przyjęcie postawy konfrontacyjnej musi doprowadzić do złych skutków. Te złe skutki to to, że w opinii świata pasmo nieporozumień między władzą a Kościołem będzie wykorzystywane przeciwko partii właśnie według prostej zasady: „[...] siły prawdziwie polskie, myślące samodzielnie, jak kościół - łatwo porozumiałyby się z Bonn, a tylko wierny Moskwie rząd polski uprawia antyniemiecką propagandę [...]". Z punktu widzenia polityki i istnienia NRD, jako niezależnego bytu państwowego, cała inicjatywa biskupów polskich, ignorująca istnienie dwu państw niemieckich, była bez sensu, bowiem między PRL a NRD żadne problemy i kwestie sporne nie istnieją: , „[...] i nie trzeba żadne-

roku jako dokument tajny opracowany przez J. Świerkosza - później zaś jako rękopis podpisany KB, s. 203/207 IPN BU 00445/12 t. 1/2).

${ }^{13}$ Fragment ze wspomnianej wyżej notatki.

${ }^{14}$ Notatka (poufna - AB - 24-66-65/pfu - sporządzona przez II Sekretarza Ambasady PRL w Berlinie Wschodnim S. Czarneckiego - IPN BU 02011/15 s. 32/33) z rozmowy $\mathrm{z}:$, [...] tow Voss i Heine "pierwszy to kierownik wydziału zachodnio niemieckiego, drugi kierownik wydziału państw socjalistycznych w MSZ NRD « [...] towarzysze niemieccy obawiają się, by Polska nie oceniła zbyt pozytywnie obu dokumentów [orędzie i reakcja na nie - P.Ł.], a zwłaszcza listu biskupów polskich, ponieważ są one jednoznacznie antykomunistyczne i anty NRD-owskie".

${ }^{15}$ Walter Ulbricht $\left({ }^{*} 1983+1973\right)$, Przewodniczący Rady Państwa NRD i I Sekretarz Socjalistycznej Partii Jedności Niemiec (SED). 
go więcej »pojednania « ni »wybaczenia« $[\ldots]^{116}$, a pytanie o to, czy polski Kościół nie wie, że istnieje NRD, wydawało się zasadne. Przy okazji dyskusji o "Orędziu” i opisywaniu sytuacji w Niemczech Zachodnich, w propagandzie PRL silnie akcentowano udział niemieckiego Kościoła katolickiego w budowie i kształtowaniu postaw żołnierzy Bundeswehry, starając się opisywać ten proces jako pełną kontynuację tego, co działo się wcześniej w Wehrmachcie: „W każdej jednostce [...] jest co najmniej dwóch kapłanów: jeden rzymskokatolicki i jeden ewangelicki. Jeśli w hitlerowskich dywizjach na 10-12 tysięcy żołnierzy było dwóch kapelanów to w Bundeswehrze 1 duchowny przypada na 1500 żołnierzy [...] kapelani wojskowi [...] wychowują również żołnierzy w duchu tradycji krzyżackich i pruskich, a nawet hitlerowskich [... $]^{\prime \prime 17}$. Wraz z upływem czasu, obserwując uważnie to, co się działo na niemieckiej scenie politycznej (w tym szczególnie jej kościelnej części), analizowano jej postawę wobec "Orędzia", jego skutków politycznych i możliwych zmian wynikających z tej właśnie postawy. Chcąc nie chcąc przyznawano przy tym, że inicjatywa, która wyszła od „, polskiego Kościoła”, miała istotne znaczenie dla dialogu polsko-niemieckiego i kierowała dyskusję na temat powojennych granic naszego kraju na zupełnie nowe tory, włączając w nią przy tym nie tylko środowiska katolickie ${ }^{18}$. Cytowano w doku-

${ }^{16} \mathrm{Z}$ dokumentu uwzględnionego w przypisie 14 - rozmowa z Sekretarzem Zarządu Głównego Ost CDU Pischerem: „[...] zauważył anty-NRDowski ton tego listu [...]”, s. 32, oraz odręczny dokument zatytułowany "OST-CDU” informujący o efektach rozmów z informatorami z "kierownictwa "aparatu “ CDU” (sygnatura teczki jak w przypisie 14) datowany dwukrotnie (2.12.65 i na końcu tekstu 15.12.65, podpisany „Rogoziński") na s. 26-29.

${ }_{17}$ Teczka IPN BU 0445/12 t.1/2. API Agencja Publicystyczno Informacyjna Warszawa Bracka 6/8 Poniedziałęk, 24 stycznia 1966 Nr 4/308 „Do publikacji” „Pobożna Bundeswehra" Stanisław Markiewicz. Strony w teczce 234-238.

$18, \ldots[. .$.$] Grupa nosząca roboczą nazwę »grupy Bensberg « od nazwy miejscowości$ pod Kolonia, ma liczyć już 800 osób [...] Jednym z pierwszych zadań [...] ma być wypracowanie »nowej polityki« katolików niemieckich wobec Polski. Na kierunek tej »nowej linii« wskazuje wypowiedź korespondentki DPA [Deutsche Presse Agentur - P.Ł.] w Polsce - Renaty Marsch [* 06.1935 - żyje i mieszka w Polsce na Mazurach - P.Ł.], według której w niemieckich kołach katolickich istnieją tendencje nie odpowiadające oficjalnej polityce rządowej a związane z poglądami wyrażanymi w znanym memorandum kościoła ewangelickiego [...]" s. 40. Dokument znajdujący się w zbiorze pod sygnaturą IPN BU 02011/15 - notatka dotycząca działalności katolików niemieckich w dokumencie „Ministerstwo Spraw Wewnętrznych Departament I L.dz. OCH - 0961/67 Warszawa dnia 18.III.1966 - podpisano Dyrektor Departamentu I MSW". 
mentach fragmenty z dziennika „Die Welt”, w których optymistycznie oceniano pochodzącą z Polski kościelną inicjatywę, widząc w niej punkt zaczepienia: „,[...] dla szczerego i dobrego klimatu rozmowy [...] $]^{19}$.

By nie było „zbyt pięknie”, zastanawiano się przy tym, czy następujące zmiany $\mathrm{w}$ sposobie myślenia $\mathrm{w}$ Niemczech nie są efektem akcji o charakterze: „[...] dywersyjno-politycznym, będącą konsekwencją wymiany orędzi między episkopatem polskim i niemieckim [...]". Próbowano też znaleźć w aktywności strony niemieckiej ślady doraźnej obrony kardynała Stefana Wyszyńskiego, którego w różnych niemieckojęzycznych mediach wyraźnie odróżniano od Gomułki ${ }^{20}$, przed atakami „władzy ludowej” oraz: „,[...] neutralizacji niekorzystnych dla NRF politycznych skutków orędzia biskupów polskich bez angażowania rządu NRF i osiągnięcia konkretnych korzyści w dziedzinie współpracy z episkopatem polskim" ${ }^{21}$. Dostrzegając w "Orędziu” dokument polityczny, Niemcy nie uciekali od trudnych dla siebie problemów i pytań stawianych przez polskiego kardynała. Dotyczyły one efektów wojny, która wepchnęła Polskę „w objęcia komunizmu i ateizmu”, a także i tego, że to $\mathrm{z}$ ich winy granica polsko-niemiecka przebiega tak właśnie, jak przebiegała w 1965 roku $^{22}$. Te sformułowania zadawały kłam propagandzie komunistów o „wyprzedawaniu” przez Kościół polskich interesów narodowych. Oczywiście jeden czy drugi tekst na ten temat

${ }^{19}$ Teczka IPN BU 01439/64 - „Die Welt” 11 grudnia 1965, s. 89.

${ }^{20}$ IPN BU 0445/12 t.1/2. Tłumaczenie z "Neue Züricher Zeitung”, "Kardynał Wyszyński - Prymas Polski przeciwnik Gomułki” 25 stycznia 1966: „,...] Wiele typowych polskich cech narodowych [...] gorący patriotyzm [...] Obcesowość, impulsywność i skłonności do gniewu zbiegają się z pokorą i samodyscypliną [...] Zdrowy ludzki rozsądek idzie w parze z sentymentalizmem, wielkoduszność do ?? reagowania na drobiazgi. Ponad tym wszystkim widnieje iście »pańskie zachowanie się« [...] Pod jednym względem przewyższa Wyszyński szefa partii [...] jest człowiekiem, którego potęga tkwi w przemówieniu. Jego kazania stały się ostrą bronią. Swoim jasnym, klasycznym, czysto polskim językiem przewyższa szefa partii [...]", s. 61-62.

${ }^{21}$ Dokument cytowany w przypisie 19, s. 39.

${ }^{22}$ IPN BU 1439/64 artykuł z "Stuttgarter Zeitung” z 3 grudnia 1965 roku: „[...] Wy Niemcy widzieliście tylko cierpienia, które zgotowała wam linia Odra-Nysa, ale nie widzieliście, że dzieli ona co prawda Niemcy od Polski, ale nie dzieli Wschodu od Zachodu. Ta granica leży na polskiej granicy wschodniej, która nie z naszej winy, biegnie tak daleko na zachód. Zrozumcie, że możemy utrzymać nasz duchowy bastion przeciwko komunizmowi [...]”, s. 88. „Die Welt” zaś z 11 grudnia sygnalizował, opinię kardynała o tym, że polskie ziemie zachodnie nie są żądną przestrzenią życiowa, ale obszarem, którego Polacy potrzebują dla swojej normalnej egzystencji, s. 89. 
zamieszczany $\mathrm{w}$ niemieckiej prasie ataków też nie mógł przerwać, bo, po prostu, było na nie zapotrzebowania polityczne.

$\mathrm{W}$ znajdujących się $\mathrm{w}$ przeglądanych przeze mnie teczkach archiwalnych dokumentach widać wyraźnie, że Niemcy doskonale orientowali się $\mathrm{w}$ prowadzonej przez polskich komunistów grze i próbach manipulowania zarówno jedna, jak i drugą stroną. Dawano temu wyraz $\mathrm{w}$ prasie, radiu i telewizji. Część z tych audycji była monitorowana przez polskie służby dyplomatyczne i tajne. Klasycznym przykładem jest tu znajdujący się w aktach „Stenogram - dialogu pomiędzy Prezesem EKD [Evangelische Kirche in Deutschland - P.Ł.] - Kurtem Scharfem ${ }^{23}$ i redaktorem »Die Zeit« - Hansjacobem Stehlem ${ }^{24}$, przeprowadzonego przed kamerami zachodnioniemieckiej TV" ${ }^{25}$. Oto fragmenty tej rozmowy:

,[...] Stehle: W oficjalnych komentarzach polskich przypisano panu, panie Prezesie, że wyczytał pan z listu polskich biskupów, iż są oni gotowi do tego, aby z nimi prowadzić »rozmowy w sprawie granic«.

Scharf: To jest nieporozumienie ze strony rządu warszawskiego. Ja nigdy nie przypuszczałem, że polscy katoliccy biskupi myślą w tym przedmiocie inaczej, aniżeli rząd i naród polski. Ja chciałem jedynie nawiązać do słowa: »dialog «, które jest zawarte w liście biskupów polskich i wyraziłem z tego powodu swoją radość, że problem granic jako całość ponownie ma być przedyskutowany w rozmowie, w dialogu.

Stehle. Co miał pan tutaj na uwadze mówiąc: problem granic?

Scharf. Mówiąc to mam na uwadze problem praw mniejszości, uzyskanie prawa do własności dla ludności mieszkającej zarówno po jednej jak i drugiej stronie granicy, a także zagadnienia indywidualnego, prywatnego zadośćuczynienia dla polskich obywateli za krzywdy, jakie spotkały ich ze strony narodowosocjalistycznych władz okupacyjnych. $Z$ problemem granic powiązanych jest wiele zagadnień natury prawnej,

${ }^{23}$ Kurt Scharf ( $\left.{ }^{*} 10.1902+03.1990\right)$, Przewodniczący Rady Kościoła Ewangelickiego w Niemczech, w połowie lat trzydziestych więzień Sachsenhausen, w latach 1966-1976 Biskup ewangelicki dla Berlina i Brandenburgii, Przewodniczący „Akcji Znak Pokuty”.

${ }^{24}$ Hansjacob Stehle *1927, na przełomie lat pięćdziesiątych i sześćdziesiątych akredytowany w Polsce jako jeden z pierwszych niemieckich dziennikarzy (1957-1961 „Frankfurter Allgemeine Zeitung”), watykanista, historyk, publicysta,

${ }^{25}$ IPN BU 02011/15 dokument podpisany „Opr. AG.” z adnotacją „Odb. 3 egz." datowany na 31 marca 1966 roku znajduje się w przywołanej teczce na s. 155-153, 
w tym również zagadnień kontaktów kulturalnych i o tych sprawach trzeba prowadzić rozmowy [... $]^{\prime 26}$.

Komuniści polscy widzieli koincydencję między wszystkimi tymi zdarzeniami, tworzący zaś równocześnie omawiane dokumenty, co paradoksalne, nie chcieli jej widzieć.

\section{Opinie o polskim Kościele}

Opinie te prezentowano $\mathrm{z}$ „własnego" komunistyczno-esbeckiego punktu widzenia i m.in. na podstawie rozpoznania i rozpracowania operacyjnego. Jeszcze przed podpisaniem przez Stefana Wyszyńskiego „Orędzia" bardzo uważnie obserwowano to, co dzieje się w Rzymie, gdzie przebywali polscy biskupi. Szczegółowo informowano np. o ilości korespondencji, jaką otrzymywali hierarchowie przebywający na Soborze Watykańskim II $^{27}$.

Jak sądzę, nie bez przyczyny $\mathrm{w}$ policyjnych dokumentach, które przeglądałem, znalazła się niedatowana notatka/instrukcja: „Aktualne problemy polityki kościoła i zadania organizacji partyjnych $[\ldots]^{\prime 28}$ zawierająca m.in. wykładnię działań dla aparatu bezpieczeństwa PRL wobec Kościoła właśnie. Opisywano w niej dobre i złe strony „współżycia” komunistycznego państwa z instytucjami katolickimi. Rzecz jasna, tych złych stron było znacznie więcej niż dobrych, a cała wina za pogarszanie się atmosfery leżała po stronie katolików i hierarchii kościelnej wzmagającej od dłuższego czasu: „[...] ofensywę polityczną wymierzoną przeciw władzy ludowej, obliczoną na skłócenie ludzi wierzących i niewierzących [...] rozbicie jedności narodu zajętego twórcza, pokojową pracą [...] Aspiracje polityczne hierarchii kościelnej [...] stano-

\footnotetext{
${ }^{26}$ Ibidem, s. 154-153.

${ }^{27}$ IPN BU 0445/12 t. 2. Teczka nr 3. Notatka na podstawie materiałów Biura "T" $\mathrm{i}$ „,W” Warszawa dnia 30.IX. Tajne Spec. Znaczenia otrzymują tow. płk. Morawski, ppłk. Straszewski, mjr. Drobot, odbita w 3 egz.: „,[...] Nie obserwujemy dotychczas wzmożonej korespondencji z biskupami przebywającymi w Rzymie. Na przykład do kard. Wyszyńskiego skierowano od 21.IX do 29.IX br. 15 listów i pocztówek / przeważnie pozdrowienia od księży i sióstr zakonnych/. Podobne treści kieruje się do pozostałych biskupów n. p. w dniu 29.IX br. Do biskupa Klepacza skierowano ponad 40 listów i kart z okazji imienin [..." $]^{\prime \prime}$, s. 21.

${ }^{28}$ IPN BU 1439/64, s. 2-12 i nn.
} 
wią przyczynę trudności w normalizacji stosunków między kościołem a państwem $[\ldots]^{\prime 29}$.

Wyraźnym przykładem chęci dominowania nad władzą świecką i zdobywania zwolenników miała być pielgrzymka Obrazu Matki Boskiej Częstochowskiej po Polsce: „,...] Dotychczasowy przebieg tej wędrówki ujawnia poza religijne cele jakie przy tej okazji usiłuje osiągnąć episkopat. Staje się ona bowiem »unowocześnioną" metodą nawracania na? wiarę przy pomocy środków antykomunistycznych $[\ldots]^{\prime 3}{ }^{30}$. Według anonimowych autorów dokumentu, do zwalczania komunistów i ich wpływów "używano" też ustawy dopuszczającej przerywanie ciąży. Zadziwiające, ale argumenty przemawiające za tą ustawą używane w roku 1965, niczym nie różnią od tych, które stosowane są w celu jej poparcia dzisiaj ${ }^{31}$.

Równocześnie wskazywano na pozytywne przykłady współpracy innych wyznań $z$ władzą (w pozostałych krajach socjalistycznych i PRL), konfrontując je od razu z pozycją i postawą Kościoła w Polsce ${ }^{32}$.

W sumie odmawiano i Kościołowi, i jego „książętom” prawa do zabierania głosu w jakichkolwiek sprawach związanych z życiem społecznym w Polsce: „[...] Kto jak kto, ale właśnie hierarchia rzymsko-katolicka nie ma jakiegokolwiek prawa mówić o trosce o ludzi pracy i wysuwać oskarżeń wobec władzy ludowej $[\ldots]^{33}$.

W prezentowanych materiałach pojawiły się też dwa interesujące anonimowe opracowania (jedno z 20 grudnia 1965 roku, drugie

${ }^{29}$ Ibidem, s. 2-3.

${ }^{30}$ Ibidem, s. 9.

31 ,"...] kampania ta zaczęła się od napaści biskupów na ustawę o dopuszczalności przerywania ciąży i politykę świadomego macierzyństwa [...] Propagujemy planowanie rodziny po to, by nie było tragedii matek obarczonych nadmierną liczbą dzieci, którym rodzice nie mogą zapewnić minimum utrzymania. Nie propagujemy wcale przerywania ciąży, przeciwnie uważamy, je za środek szkodliwy dla zdrowia kobiety, dopuszczalny tylko w ostateczności [...]", s. 11, ibidem.

${ }^{32}$, ,...] W ustroju socjalistycznym stosunki między państwem a kościołem mogą układać się poprawnie. Wskazuje na to doświadczenie wielu kościołów chrześcijańskich, tych w Polsce jak i w innych bratnich krajach. Świadczy o tym stosunek kościoła prawosławnego do państwa w ZSRR, Bułgarii, Rumunii oraz stosunek kościoła ewangelicko-augsburskiego i innych wyznań do PRL [...]", s. 4, dokument cytowany w przypisie 28 i niżej.

${ }^{33}$ IPN BU 1439/64, s. 12. 
z 10 stycznia 1966 roku $^{34}$ ), pokazujące, w jakim kierunku powinna iść propaganda komunistyczna $\mathrm{w}$ omawianiu interesującej nas problematyki. W pierwszym $\mathrm{z}$ tych dokumentów przyjęto następujące założenia: „Orędzie” było reakcją i skutkiem „nacjonalistycznej”, tak miłej władzom PRL, postawy Kościoła podczas obchodów (Olsztyn, Szczecin, Opole i szczególnie Wrocław) dwudziestolecia obecności polskiej administracji kościelnej na terenach, które przypadły Polsce po wojnie. Efektem tej postawy były naciski kurii rzymskiej i niemieckich biskupów. Według wspomnianego dokumentu: „[...] kard. Doepfner stwierdził, że pojednawczy ton listu jest jego zasługa, gdyż dwukrotnie rozmawiał z Wyszyńskim tłumacząc mu niewłaściwość wystąpień episkopatu polskiego we Wrocławiu [...]"35. W efekcie, polski episkopat odszedł od „,tonacji wrocławskiej" i zaczął usprawiedliwiać się przed niemiecką opinią publiczna, zdradzając, de facto, polskie interesy narodowe. To z kolei według autorów (autora!?) dokumentu wywołało ogromne społeczne wzburzenie, które było wielkim zaskoczeniem dla episkopatu ${ }^{36}$. Sygnalizowano przy tym napisy, jakie pojawiały się $\mathrm{w}$ miejscach publicznych, w tym na świątyniach: „,[..] Rybnik - bud. Szkoły: »nie chcemy biskupów niemieckich«, Bielsko - budynek: »chcemy wyjaśnień dla czego zdradzili«, na frontonie budynku ZSP »przecz z episkopatem«, w Krakowie na kościele: »precz z arcybiskupem zdrajcąu, w Szczecinie - 19.XII. na drzwiach kościoła: »Precz« [...]”. Sygnalizowano też po-

${ }^{34}$ IPN BU 1439/64 „Tezy do tematu »Orędzie«" tajne egz. nr 1, Warszawa, dnia 20 grudnia 1965, s. 49-52. oraz „Tezy oparte na tematyce »Orędzia biskupów polskich« i listu - odpowiedzi biskupów niemieckich - do ewentualnego opracowania" tajne, Warszawa, dnia 10 stycznia 1966, s. 90-93. Oba dokumenty zostały odtajnione 13 lutego 1993 roku.

${ }^{35}$ Dokument wyszczególniony w przypisie 30 „Tezy do tematu...” s. 49. Podobna opinia: „,[...] W orędziu przemilcza się w ogóle fakt powstania biskupstwa misyjnego w Polsce $\mathrm{z}$ biskupem Jordanem na czele, co jest zrozumiałe jeśli uwzględnić fakt, że redagowali orędzie Niemcy [...] " pojawia się w dokumencie „Tezy oparte na tematyce [...]", przywołanym w przypisie 30, na s. 90 .

${ }^{36}$ Cytowany dokument: „,[...] potępienie episkopatu, orędzia i jego inicjatorów [...] niektórzy księżą i osoby świeckie - nie wierza, że biskupi mogli taki list wydać, w początkowym okresie istniała dezorientacja; niektórzy księża myśleli, że Państwo winno być zadowolone z tego dokumentu; później zaczęli się domagać od swoich przełożonych wyjaśnień / przełożeni wyrażali niewiedzę, odsyłali nawet do prasy/, reagowanie wiernych dość gwałtowne / domaganie się wyjaśnień, odchodzenie od kościoła - »skoro biskupi sprzedają naród « [...]", s. 51 . 
jawiające się wrogie dla władzy napisy i działania nie egzemplifikując ich jednak ${ }^{37}$. Z satysfakcją obserwowano też postawę środowisk „katolików świeckich": „[...] posłowie w Sejmie; Tyg. Powszechny - nie chce przeciwko Wyszyńskiemu, ale obawia się władz; przyjęto kompromis - zrobić artykuł; cenzura go zdjęła - cieszą się, że mają wobec Państwa alibi /chcieli ale cenzura nie dała/, a stosunków z Wyszyńskim nie zadrażniono; - Pax - początkowo wyczekiwanie, później włączenie się"38. W kolejnym opracowaniu noszącym charakter „naukowego”, którego tezy miały służyć uzasadnianiu ataków na Kościół, zastanawiano się nad powodami wystosowania listu, zwracano uwage na „historyczne” błędy zawarte w „Orędziu”. Głównym z nich było zwrócenie się z przesłaniem głównie do Niemców, a nie do Czechów, bo: „[...] Przecież Dobrawka, na którą powołuje się »orędzie« była księżniczką czeską, skoro więc za jaj wpływem Mieszko przyjął chrzest - to skoro więc za jej wpływem Mieszko przyjął chrzest - to wypadało zaprosić przede wszystkim biskupów czeskich"39. Ten ton był wyraźny także w odniesieniu do i w przeciwieństwie do opisywanego w "Orędziu” podziału administracyjnego „Polski Piastowskiej”, a także działań politycznych pierwszych Piastów zbliżających nasz kraj do Zachodu, które w oczach autorów „Tez" dystansowały wręcz Polskę od Cesarstwa Ottona III, tym samym wzmacniając jej suwerenność w sferze politycznej, a także i kulturowej. „Orędzie” więc w swej istocie było i musiało być antypolskie i antypaństwowe: „,[...] to sformułowanie jest dla Polski, dla polityki piastowskiej, zwłaszcza polityki Mieszka I i Bolesława Chrobrego krzywdzące; Polska byłą suwerenna, swą suwerenność utwierdzała i nie była żadnym >»złonkiem Imperium Romanum Ottona III«, zwłaszcza Ottona III. [...] W długim akapicie »orędzia« [...] podkreśla się przesadnie i jednostronnie zasługi niemieckie dla kultury polskiej. Bez mała się twierdzi, że kultura polska jest powtórzeniem kultury niemieckiej. Historycy kultury polskiej wykazali, że tak nie jest $[. . .]^{\prime \prime 40}$. Biskupi zaś wzorem Stanisława ze Szczepanowa stali się (publikując orędzie) faktycznymi

\footnotetext{
37 Ibidem, s. 51.

${ }^{38}$ Ibidem, s. 52.

${ }^{39}$ IPN BU 1439/64 „Tezy oparte na tematyce »Orędzia«...” podkreślenie w tekście tak jak w dokumencie, s. 90.

${ }^{40}$ Ibidem, s. 91.
} 
zdrajcami $^{41}$. W dalszym ciągu wywodów pojawiają się też argumenty z najnowszej historii naszego kraju. Ukazuja co najbardziej „bolało” ówczesne władze w „Orędziu”. Były to nie tylko inne, niż nakazywane przez komunistów, opinie o kształtowaniu stosunków polsko-niemieckich, ale także podkreślanie suwerenności Kościoła wobec władzy państwa, zupełnie odmienna od „oficjalnej” wizja końca i efektów wojny dla Polski i Polaków; wreszcie zaś pojawienie się Kościoła jako samodzielnego gracza na politycznej arenie. Gracza, który miał swoje zdanie (w sposób istotny odmienne) od władzy w wielu ważnych dla narodu kwestiach. Problem polegał na tym, że totalitarna władza (co wynikało $\mathrm{z}$ jej istoty, której jednym $\mathrm{z}$ podstawowych elementów był strach przed wolnością) nie chciała w żadnym wymiarze dzielić się czymkolwiek z kimkolwiek, uważając przy tym, że ma monopol na prawdę i „rząd dusz". Kościół, jego postawa i działanie pokazywał, że jest to postawa niewłaściwa. To zaś było dla komunistów trudne do zaakceptowania, każda więc metoda, łącznie z kłamstwem i manipulacją (w tym szczególnie odmawianie patriotyzmu i uleganie wrogim Niemcom), by Kościół dyskredytować, była dobra ${ }^{42}$.

${ }^{41}$ Ibidem, s. 92. "[...] Uwaga praktyczna Nie należy śpiewać »Gaude mater Polonia«, jak to miało miejsce podczas uroczystości 600 lecia U.J. w Krakowie, a jeszcze bardziej w ChAT czy ATK. Pieśń bowiem sławi Stanisława ze Szczepanowa, który był klasycznym zdrajcą racji stanu. Nawet Gall nazwał go mianem »traditor « - zdrajca".

${ }^{42}$ IPN BU 1439/64: , ,[...] 7. Orędzie, mówiąc o 150-letniej niewoli Polski pod zabora$\mathrm{mi}$, ani słowem nie wspomina o powstaniach - styczniowym, listopadowym, insurekcji kościuszkowskiej - wiadomo dla czego: powstania zostały potępione przez papieży. Wdzięczny temacik. 9. czy słuszny jest zwrot »orędzia« - »próbujemy zapomnieć« w stosunku do zbrodni niemieckich w Polsce? [...] to znaczy nie stawiać pomników, nie upamiętniać miejsc straceń [...]. Łatwo mówić o zapominaniu, gdy się nikogo i niczego nie straciło. [...] 11. Polska 1944 roku - państwo zwycięskie czy zwyciężone? Teza jako polemika ze sformułowaniem »orędzia« głoszącym, że Polska „wyszła z okresu masowych mordów nie jako państwo zwycięskie. [...], s. 13. Z odpowiedzi niemieckiej [...] widać, że chodzi przede wszystkim o tzw. dialog. Czego on ma dotyczyć? W czyim imieniu ma być prowadzony? jakie mają być spodziewane efekty? Widać wyraźnie, że chodzi tu o wpływ na opinie publiczną, a przez nią na politykę. 14. Ziemie Zachodnie - czy »tereny przydzielone« / list niemiecki / i »tereny poczdamskie« / »orędzie« polskie/. Czy też piastowskie ziemie »po wiekach odzyskane«/Jan XXIII/. Jeśli Ziemie Zachodnie były polskie od stuleci - to nie może być mowy o »wezwaniu Niemców przez swych rodzimych książąt «i tzw. prawie od ojczyzny w odniesieniu do tych terenów", s. 92-93. 
W sposób aktywny analizowano i przytaczano także opinie niemieckie odnoszące się do Kościoła, hierarchów i katolicyzmu w Polsce. We wspomnianym już dokumencie ${ }^{43}$ odwoływano się do wypowiedzi Herberta Czaji wspominającego w sposób „,...tendencyjny i jadowity..." trudny los polskiego Kościoła, gnębionego podobnie jak w ZSRR podatkami, które obejmują cały obszar działalności tej instytucji. Wierni chcący chodzić na msze i prowadzić prace formacyjne są narażeni na liczne trudności w pracy. Przy okazji Czaja poświęcał nieco miejsca „księżom patriotom”, określając ich rolę jako niewielką. Odnotowywał też znaczny wpływ , „[...] Urzędu do spraw wyznań oraz tajnej policji na zagadnienia kościelne [...]". Kościół jednak swoją postawą różną od PAX-u ${ }^{44}$ i ,[...] lewicowych prawowiernych katolików »Znak « [...]" powodował, że wielu wiernych stoi przy nim twardo, przeciwstawiając się silnym prądom laickim. Polski katolicyzm poniósł w czasie wojny i okupacji ogromne straty, a i Polacy zostali zdemoralizowani: „[...] na skutek warunków stworzonych przez Rosja?? [...]" ${ }^{\prime 45}$. Opisując sytuację w Polsce i postawę Kościoła zwracał też Czaja uwagę na elementy antysemityzmu: „,...] Nie mówię tego - powiada Czaja w referacie - bynajmniej dla tego aby potworności Oświęcimia porównywać z polskim antysemityzmem, co usiłuje się w ostatnim czasie czynić z niektórych stron. Uważam podobne porównania za niemożliwe [...]"46. Konkluzją jego wystąpienia było stwierdzenie, że należy pracować w duchu zjednoczonej Europy i starać się nawiązywać dialog z polskimi „braćmi w wierze”, a także udzielać im i Kościołowi w Polsce możliwie dużej pomocy we wszelkim wymiarze z położeniem nacisku na „dia-

${ }^{43}$ Zob. przypis 8 na s. $116-117$.

${ }^{44}$ Niemiecka ocena postawy PAX-u połączona z historycznym wartościowaniem „polskiego katolicyzmu” zawarta jest we fragmentach dokumentu cytowanego w przypisie 13: „[...] Do tego [...] można dodać: katolicy niemieccy podziwiają bohaterski opór stawiany przez polskich katolików nacj.socjal, podziwiają opór polskiego episkopatu i wiernych [...] przeciwko prześladowaniom komunistycznym. Ale odrzucają oni organizację PAX jako przedstawicieli wszystkich polskich katolików. Przywódcy PAX rekrutują się z faszystowsko-antysemickich falangiotów [tak w tekście - P.Ł.], którzy podczas II Wojny Światowej najpierw z Gestapo współpracowali potem z MWD. Po zakończeniu działań wojennych zwalczają kościół katolicki wspólnie z komunistami [...] nie kwalifikują się być pośrednikami między polskimi i niemieckim katolikami [...]", s. 206-207.

${ }^{45}$ Sygnatura dokumentu jak w przypisie 8, s. 39.

${ }^{46}$ Cytowany wyżej dokument o sygnaturze IPN BU 02011/15, s. 38. 
$\log ^{\prime \prime 4}$. Gdy przy tej okazji wspominał o tym, by władze RFN troszczyły się bardziej o Polaków w Niemczech (jakże to aktualny, mimo upływu lat, postulat!), to niewątpliwie oprócz humanistycznych przesłanek przyświecały tym wypowiedziom także i względy praktyczne: ,„[...] Polskie życie organizacyjne zależne jest od państwa, a to chciałoby w ogóle bezojczyźnianych obcokrajowców chętnie wykorzystywać dla swoich służb informacyjnych $[\ldots]^{\prime \prime 48}$.

Przytaczając oceny polskiego Kościoła za krajową prasa, nie stroniono też $\mathrm{w}$ niemieckich mediach (co znajdowało szerokie odbicie w przeglądanych przeze mnie teczkach) od cytowania fragmentów paszkwilanckich i zupełnie nieprzyzwoitych opinii, mających dyskredytować hierarchię kościelną. Odbywało się to trochę tak, jak w całkiem niedawnej przeszłości „niepodległej Polski”, gdy pojawiał się artykuł w polskiej prasie, który był sygnalizowany w Niemczech, a potem odnoszono się do tych cytatów w Polsce. Wpisywało się to doskonale w tendencję przypisywania Kościołowi hierarchicznemu tendencji faszystowskich i antysowieckich. I tak KNA w komunikacie z dnia 22 stycznia 1966 roku w ślad za „Trybuną Robotniczą” pisała o kardynale Auguście Hlondzie, że był zagorzałym zwolennikiem sojuszu z III Rzeszą i przeciwnikiem paktu Rzeczpospolitej z ZSRR zawartego w 1932 roku, a niedawne wystąpienie biskupów pod adresem ich niemieckich współwyznawców było tylko powtórzeniem pomysłów kardynała ${ }^{49}$. Ta tendencja

${ }^{47}$ Jak szalenie groźne dla reżimów komunistycznych było już samo słowo „dialog" i współpraca (np. młodzieżowa czy turystyczna), które każdą próbę zbliżenia traktowały jako akt agresji ideologicznej, niech świadczy znajdujący się w omawianych aktach ściśle tajny dokument „Feindliche taetigkeit westdeutscher kirchlicher Reisegruppen gegen die sozialistischen Laender unter Ausnutzung des Reise - und Touristenverkehrs" „wyprodukowany” przez STASI w pierwszych miesiącach 1968 roku. IPN BU 02011/15, s. 21.

${ }^{48}$ IPN BU 02011/15, s. 34.

${ }^{49}$ IPN BU 0445/12, t. 1/2 Dokument nr 6 z dnia 26 stycznia 1966 (odręczny dopisek na dokumencie IV.2 >?<), w komunikacie KNA nr 41 znajdującym się w wyżej wymienionej zbiorze dokumentów z dnia 17 lutego 1966 roku cytowano Mieczysława Moczara: „Warschau 16 Februar 1966 (KNA) »Einige polnische Bischoefe sind von dem Hass geblendet worden, den Kardinal Wyszynski gegenueber dem Sozialismus in Polen empfindet « betonte der polnische Innenminister [...] Moczar [...] Die Bischoefe, die den Versoenhungsapell an den deutschen Episkopat unterzeichnet haben, seien bereit »selbst mit dem Teufel zu paktieren, wenn sie dadurch in die Lage versteht wuerden, den Fortschritt in Polen zu verhindern«. Er wisse jedoch, dass nicht alle Bischoefe bereit seien, 
w opisywaniu zdarzeń wpisywała się w ogólną nagonkę na inaczej myślących, jaka miała miejsce $\mathrm{w}$ Polsce $\mathrm{w}$ tym czasie. Odnotowywano też próby obrony stanowiska zajętego przez Kościół: „,[...] Stefan Kardynał Wyszyński rozgoryczony zareagował obecnie ostro na ataki rządu, który twierdzi, że biskupi mieszają się w sprawy polityki zagranicznej [...] sekretarz polskiego episkopatu biskup Choromański zaatakował postępowanie rządu polskiego [...] Rząd domaga się od kościoła polskiego, aby podzielił jego nienawiść do Niemiec. Ale kościół nie mówi marksistowskim, komunistycznym językiem [... $]^{\prime 50}$. Było jasne, że atakowani biskupi podejmą akcję obronną. Władza przewidywała, jaką przybierze ona formę, początkowo nie znała jednak szczegółów planowanej kontrakcji. Z biegiem czasu jednak, w miarę napływu informacji pochodzących od agentury i obserwacji tego, co działo się w kościołach, definiowano to, co Kościół chciał robić i robił. Na przełomie 1965 i 1966 roku: „[...] Przystąpiono do rozwinięcia prowadzonej dotąd »kontrakcji hierarchii kościelnej « [... $]^{\prime 51}$. Miała ona polegać na akcji wysyłania petycji i protestów do władz państwa w obronie kardynała Stefana Wyszyńskiego. Inicjowano tydzień modlitw (na Jasnej Górze) w intencji obrony kardynała. W tej samej intencji modlono się w kościołach i kaplicach, wykorzystując te spotkania do: „,...] zapoznawania wiernych z ideą »orędzia«; propagowanie kościelnych uroczystości milenijnych [...]"52. Planowano także wysłanie depesz solidarnościowych do atakowanego przez komunistów Prymasa. Władza, co oczywiste, bardzo uważnie obserwowała te poczynania. Efektem tych działań była m.in. statystyka wypowiedzi biskupów w interesującej nas kwestii ${ }^{53}$. W postaci tabelarycznej ujęto imię i nazwisko konkretnego biskupa, formę wypowiedzi (tu określano ją jako pozytywną lub negatywną na forum publicznym

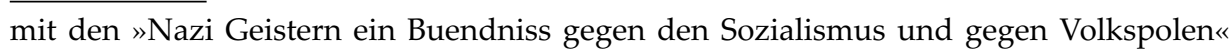
zu unterzeichnen $[\ldots]^{\prime \prime}$, s. 199.

${ }^{50}$ IPN BU 0445/12, t. 1/2 Serwis nasłuchu Polskiego Radia z dnia 26 grudnia 65 N(?) OM .Niem. Zach. Kowalski / Kosińska Kolonia, godz. 14.30,

${ }^{51}$ IPN BU 1439/64 Tajny (anonimowy i niedatowany) dokument „Dot. Planowanej »Kontrakcji Kościelnej« w obronie Kard. Wyszyńskiego i »Orędzia« do Biskupów Niemieckich", s. 43.

${ }^{52}$ Ibidem, s. 44.

${ }^{53}$ IPN BU 1439/64. "Zestawienie wystąpień biskupów w sprawie »orędzia«". Tajny dokument z dnia 29 grudnia 1965 roku. Wyk. W 5 egz. Oprac. W.I. s. 46-48. 
i prywatnym), jej ewentualny brak i to czy „Orędzie” zostało przez konkretnego członka Episkopatu podpisane. Tabelę kończyła rubryka uwagi, w której jedyną adnotacją była sentencja „....nie wrócił..." ${ }^{54}$. Według podanego klucza biskupi mieli wypowiadać się zgodnie z duchem i intencjami Kościoła 56 razy, a przeciw „Orędziu” 20, z czego 19 razy nieoficjalnie ${ }^{55}$.

Warto przy okazji zorientować się, co w rzeczywistości (czego nie oddaje esbecka statystyka) mówił i jak odnosił się do problemu Episkopat Polski i poszczególni jego reprezentanci. W komunikacie wydanym dnia 15 grudnia 1965 roku biskupi informowali opinię publiczną i władze PRL o swoim stanowisku szczegółowo je wyjaśniając. Twierdzono (zresztą zgodnie z rzeczywistością), że wiele z elementów „Orędzia" zostało przedstawionych niezgodnie z prawdą i z pełnym niezrozumieniem spraw, które zostały w nim poruszone. Broniono się także w sposób aktywny przed oskarżeniami o wyprzedaż polskich interesów narodowych ${ }^{56}$. Biskupi nie poprzestali na wydaniu komunikatu. Sami podczas mszy i spotkań z alumnami seminariów duchownych charakteryzowali i opisywali przyczynę swojej „akcji”. Powtarzano argument o tym, że "Orędzie" nie miało charakteru politycznego, lecz moralny i chrześcijański, bo taki jest duch panujący w Kościele katolickim ${ }^{57}$.

${ }^{54}$ Oczywiście musiało chodzić o powrót z Soboru. Co do sformułowań „pozytywnie" lub „,negatywnie" zamieszczono pod tabelą następujące wyjaśnienie: „[...] UWAGA 1/ wypowiedzi pozytywne odnoszą się do krytyki »orędzia« lub niektórych jego sformułowań. 2/ W pozycji »negatywne oficjalne« ujęto wystąpienia biskupów na konferencjach z księżmi i z ambon. 3/ Część biskupów nieoficjalnie wypowiadał się pozytywnie, natomiast $\mathrm{w}$ oficjalnych wystąpieniach zajmowała odmienne stanowisko. 4/ W nawiasach podano ogólną sumę wystąpień", s. 48.

${ }_{55}$ IPN BU 1439/64 dokument cytowany wyżej, s. 48.

${ }^{56}$ IPN BU 1439/64 Komunikat Sekretariatu Episkopatu z dnia 15 grudnia 1965, ,...] ujęcie tego listu zostało niekiedy przedstawione $\mathrm{w}$ prasie niezgodnie $\mathrm{z}$ obiektywnym stanem rzeczy, należy wyjaśnić, że list ten, jak wszystkie inne ma przede wszystkim charakter dokumentu kościelnego. Jest zaproszeniem do modlitwy w duchu chrześcijańskiego pokoju [...]. Nie ma więc charakteru dokumentu politycznego, w niczym nie wchodzi w prawa państwa [...] wbrew sugerowanym niekiedy opiniom list episkopatu Polski stoi na stanowisku nienaruszalności granic zachodnich Polski, [...] List uwydatnia krzywdy wyrządzone Polsce w czasie drugiej wojny światowej i dążność do biologicznego wyniszczenia narodu polskiego [...]", s. 53-54.

${ }^{57}$ IPN BU 1439/64 Ocena charakteru „orędzia” w wypowiedziach biskupów od 12 grudnia 65 , do 10 stycznia $66 .:$, ,[...] orędzie nie ma charakteru politycznego, biskupi nie są politykami a wychowawcami w duchu moralności chrześcijańskiej [...]", Arcybi- 
Podkreślano także bardzo mocno prawo Kościoła do wypowiadania się w kwestiach dotyczących polskiego życia narodowego i państwowego, co wiązało się z wolnościami obywatelskimi i nieumiejętnością oraz brakiem chęci znalezienia porozumienia między władzami PRL a RFN: ,[...] Jeżeli nie mogą dogadać się rządy to dogadają się katolicy. [...]” mówił w grudniu 1965 roku w Wyższym Seminarium Duchownym w Kielcach biskup Jan Jaroszewicz ${ }^{58}$. Wspominano o konieczności chrześcijańskiego przebaczenia Niemcom i zastanowienia się nad błędami i wyrządzonym złem (dotyczyło to i Polaków, i Niemców) ${ }^{59}$. Ważnym elementem tych wypowiedzi było podkreślanie polskiego patriotyzmu biskupów i tego, że z biegiem czasu po złej propagandzie nie pozostanie śladu, a inicjatywa Episkopatu nie tylko będzie przynosiła dobre owoce, ale także pokaże, kto lepiej i mądrzej służył Polsce i Polakom ${ }^{60}$. Podkreślano też inną formę „walki” Kościoła i jego hierarchów o prawa Polski do "Ziem Zachodnich” niż ta realizowana przez komunistów delikatnie określanych mianem „polityków” ${ }^{\prime 61}$. Definiowano też przyczyny tak gwałtownej reakcji władzy na inicjatywę Kościoła. Wiernym starano się tłumaczyć fakt pojawienia się „własnej” inicjatywy Kościoła w polityce

skup Karol Wojtyła w kazaniu w Kościele Mariackim w Krakowie dnia 31 grudnia 1965 roku, s. 96.

${ }^{58}$ Ibidem, spotkanie z profesorami Wyższego Seminarium Duchownego w Kielcach, s. 98 .

${ }^{59}$ Ibidem: „[...] obowiązuje nakaz przebaczania i rozgrzeszania. Gdyby chrześcijanie cofnęli się od tego przestali by być ludem bożym i narodem chrześcijańskim [...] Arcybiskup Karol Wojtyła, kazanie w Krakowie dnia 26 grudnia 1965 roku, s. 100, ,[...] Prosimy o przebaczenie [...] w pierwszych latach po wyzwoleniu na Ziemiach Zachodnich wyrządzano wiele zła. Pamiętamy jak jeżdżono tam na szaber, przywożono stamtąd wiele rzeczy i dopuszczano licznych nieprawości [...]" i , , [...] Wybaczenie dotyczy tylko tych, którzy nie wyrządzili narodowi polskiemu krzywdy [...]". Jan Mazur, kazania w Lublinie, kolejno 24 grudnia 65 i 25 grudnia 65., s. 96.

${ }^{60}$ Ibidem: „, [...] Nikt nas nie będzie uczył patriotyzmu [...] Biskupi polscy nigdy ziemiami polskimi nie handlowali, ale zawsze stawali $\mathrm{w}$ obronie sprawiedliwej i rzetelnej polskiej racji stanu [...]". Kardynał Stefan Wyszyński, kazanie w Gnieźnie, dnia 1 stycznia 1966, s. 103. „[...] Propaganda stopnieje i społeczeństwo przekona się kto ma rację i kto dobrze służy polskiej racji stanu [...] Kościół nigdy nie zdradził Polski, mógł niejeden biskup w historii polskiej błądzić, ale kościół nie zdradził [...]" Zygmunt Choromański, kazanie w Warszawie, dnia 25. grudnia 65 roku, s. 104,

${ }^{61}$ Ibidem: ,[...] Biskupi polscy w swoim liście stwierdzili prawa narodu polskiego do Ziem Zachodnich z granicą na Odrze i Nysie z całą stanowczością, aczkolwiek uczynili to w inny sposób niż czynią to politycy [...]", Karol Wojtyła kazanie w Krakowie dla robotników zakładów sodowych „Solvay”, dnia 27 grudnia 65 roku, s. 106. 
zagranicznej. Zwracano także uwagę na złą rolę, jaką w całej sprawie odgrywały PRL-owskie media, w tym szczególnie prasa manipulująca tekstem „Orędzia”. ${ }^{62}$

Reasumując, dokumenty ze zbioru, do którego dotarłem (dzięki pomocy dr. Władysława Bułhaka), jak już wyżej pisałem, nie zmieniają naszej optyki dotyczącej problematyki „Orędzia”. Odkrywają jednak w znacznym stopniu kuchnię komunistycznej manipulacji, pokazują obszary, które najbardziej interesowały władze PRL w stosunku do strony niemieckiej, pokazują także obawy i postawy niemieckie wynikające ze zdarzeń roku 1965. Wydaje się też, że dokumenty, które tu wykorzystałem, prowokują do postawienia nowych pytań/problemów badawczych. Byłyby one następujące: jak media w PRL realizowały zalecenia władz wobec Kościoła katolickiego „po Orędziu”; jakie reakcje społeczne miały miejsce w Polsce po inicjatywie polskich biskupów; jaka była (i czy miała w ogóle miejsce) współpraca między polskimi a specjalnymi służbami NRD w akcji przeciwko polskiemu Kościołowi w interesującym nas aspekcie i momencie historycznym, czy STASI próbowała w tej grze być niezależnym podmiotem (tu, i nie tylko tu, są potrzebne badania archiwów w Instytucie Gaucka); jaka była rola innych Kościołów chrześcijańskich w Polsce w rozgrywce z Kościołem katolickim (a może tej roli wcale nie było), którą komuniści mogli wyznaczać, nieświadomym tego wspólnotom i duchowieństwu.

Chcąc zrozumieć i poznać swoją najnowszą historię powinniśmy sobie na te pytania wyczerpująco odpowiedzieć.

${ }^{62}$ IPN BU 1439/64 - dokument cytowany wyżej: „,[...] Powiadają dla czego biskupi nie uzgadniają z rządem polskim tego listu? A ja się zapytam - jak mogli uzgadniać kiedy od 2-ch (?) lat nie chcą z nami rozmawiać. Ja się domagam, proszę, piszę i na to nie ma odpowiedzi. Z kim mieliśmy uzgadniać kiedy nie chcą zwracać uwagi na nas? [...]", Zygmunt Choromański, kazanie w Warszawie, dnia 25 grudnia 65, s. 109, ,[...] Zaraz po powrocie prymasa zaczął się ten jazgot, taki wrogi, taki niepolski zupełnie [...]", Zygmunt Choromański, kazanie w Warszawie, dnia 19 grudnia 65, s. 110, ",[...] Cel kampanii - świadome odrywanie katolików od biskupów. W szkołach każe się dzieciom pisać wypracowania przeciwko biskupom [...]", Wilhelm Pluta, kazanie w Gorzowie, dnia 21 grudnia 65, s. 111, ,[...] z punktu widzenia prawa, prasę polską można zaskarżyć o rozgłaszanie zniekształconej treści listu [...]", Karol Wojtyła, z wystapienia na konferencji dla księży, dnia 22 grudnia 65, s. 112. Mam nadzieję, że w najbliższym czasie szerzej omówię postawę prasy krajowej wobec „sprawy Orędzia”. 


\begin{abstract}
A gloss to the echo, in the documents of the Institute of National Remembrance, of the Polish bishops' letter of $18^{\text {th }}$ November 1965 to the German bishops

The article refers to source materials in respect of the Polish bishops' letter of 18th November 1965 to the German bishops, held in the archives of the National Remembrance Institute. Some of these materials are unknown to researchers. They are not significant enough to alter either our vision of the events related to the letter, or of its impact on the Polish-German relations; they may well, however, extend this knowledge to a substantial degree and complement it. These materials originate not only from the Polish special services, but also from the East German STASI.
\end{abstract}

